\title{
Perbedaan Hasil Belajar Siswa Menggunakan Modul Berbahasa Inggris dan Buku Bilingual pada Materi Laju Reaksi Kelas XI SMA
}

\author{
Diterima 27 Maret 2018, Disetujui 27 Maret 2018, Dipublikasikan April 2018
}

\author{
A Hardinata ${ }^{1, a)}$, Ellizar $^{2}$, dan Andromeda ${ }^{2}$ \\ ${ }^{1}$ Departemen Pendidikan IPA, Universitas Negeri Padang, Jl. Prof. Dr. Hamka, Air \\ Tawar, Padang, Indonesia \\ ${ }^{2}$ Departemen Kimia, Universitas Negeri Padang, Jl. Prof. Dr. Hamka, Air Tawar, \\ Padang, Indonesia \\ ${ }^{a)}$ E-mail: hardinata.a@fmipa.unp.ac.id
}

\begin{abstract}
Abstrak. Telah dilaksanakan penelitian pendidikan untuk melihat perbedaan hasil belajar siswa SMA pada pembelajaran Laju Reaksi dengan menggunakan modul berbahasa inggris dan buku bilingual. Modul yang digunakan merupakan modul pembelajaran laju reaksi yang telah dikembangkan oleh peneliti sebelumnya dan buku bilingual yang digunakan merupakan buku komersial yang beredar di masyarakat. Metode penelitian yang digunakan adalah metode eksperimen dengan rancangan Randomized Control Group Only Design. Sampel diambil dua kelas secara acak dari tujuh kelas siswa kelas XI di SMA kota Padang. Pengumpulan data dilakukan dengan menggunakan instrument tes objektif sebanyak 20 soal. Data yang diperoleh dianalisis dengan menggunakan uji perbedaan dua rata-rata (t-tes). Hasil penelitian menunjukkan bahwa kelas yang menggunakan modul berbahasa inggris memiliki rata-rata nilai $(89,06)$ yang lebih tinggi dibandingkan dengan siswa yang belajar menggunakan buku bilingual $(70,00)$. Berdasarkan uji hipotesis dengan uji satu pihak atau uji t', diperoleh bahwa hasil belajar siswa yang menggunakan modul berbahasa inggris lebih tinggi secara signifikan dibandingkan dengan siswa yang menggunakan buku bilingual di kelas XI SMA Kota Padang.
\end{abstract}

Kata kunci: modul berbahasa inggris, buku bilingual, laju reaksi, hasil belajar

\section{Pendahuluan}

Kemajuan ilmu pengetahuan dan teknologi yang disertai dengan semakin kencangnya arus informasi dan globalisasi dewasa ini menuntut semua bidang kehidupan untuk menyesuaikan visi, misi, tujuan, dan strateginya agar sesuai dengan kebutuhan dan tidak ketingalan zaman. Penyesuaian tersebut secara langsung mengubah tatanan sistem dalam kehidupan manusia, salah satunya pada sistem pendidikan. Sistem pendidikan nasional harus dikembangkan sesuai dengan kebutuhan dan perkembangan global. Salah satu kebijakan pemerintah pusat dalam rangka peningkatan kualitas pendidikan di Indonesia adalah penyelenggaraan Sekolah Bertaraf International (SBI) (UU RI No. 20 tahun 2003 dan PP No. 19 tahun 2005). Sekolah Bertaraf International ini menerapkan bahasa inggris dalam pembelajaran dikelas. Kebijakan SBI diharapkan dapat menjadi faktor pendorong bagi pemerintah guna meningkatkan kualitas pendidikan di Indonesia. Pengembangan SBI bertujuan untuk meningkatkan kinerja sekolah dalam mewujudkan tujuan pendidikan nasional secara optimal dan meningkatkan mutu pelayanan pendidikan dalam mempersiapkan lulusan SMA yang memiliki kompetensi sesuai dengan standar kompetensi lulusan (Triwiyanto, 2010). Proses pembelajaran di SBI mengutamakan pembelajaran yang interaktif, inspiratif, menyenangkan, dan menantang sehingga memotivasi siswa berperan aktif dalam pembelajaran. Agar siswa berperan sebagai subjek dalam kegiatan pembelajaran, guru berperan untuk merencanakan pembelajaran yang menuntut siswa banyak melakukan aktivitas belajar. 
Jurnal SEMESTA, Vol.01, No.01, 2017 pp. 6-12

Situmorang dkk (2015) mengatakan bahwa penerapan belajar mengajar secara bilingual dengan bahasa inggris sebagai bahasa kedua telah meningkat di banyak negara termasuk Indonesia. Negara-negara berkembang seperti Indonesia tidak dapat lepas dari penggunaan bahasa inggris sebagai bahasa kedua. Hal ini tidak terlepas dari ditetapkannya bahasa inggris sebagai bahasa international. Kemampuan berbahasa merupakan salah satu kecerdasan yang harus dimiliki siswa. Kemampuan berbahasa atau berkomunikasi merupakan salah satu kecerdasan majemuk yang diharapkan dimiliki oleh siswa. Siswa yang belajar bahasa kedua selain bahasa ibunya memiliki tingkat kognitif yang tinggi dibandingkan siswa yang hanya mampu menguasai bahasa ibunya (Foster dkk, 1989). Siswa yang memiliki bahasa kedua selain dari bahasa sehari-harinya memiliki kemampuan kognitif yang lebih tinggi sehingga diharapkan mampu menyelesaikan permasalahan yang dihadapinya dalam kehidupan sehari-hari. Landry (1973) juga menyebutkan bahwa siswa yang belajar bahasa kedua selain bahasa sehari-harinya menunjukkan bahwa siswa tidak hanya meningkatkan kemampuan pendekatan traditionalnya dalam menyelesaikan masalah, tapi juga memberikan kemungkinan terhadap mereka kaya akan sumber ide yang berbeda dan terbaru. Selain memiliki kelebihan dari segi kognitif, diharapkan siswa yang menguasai bahasa kedua yakni bahaasa inggris juga unggul dibidang lainnya. siswa Itali yang menguasai bahasa Itali dan bahasa inggris memiliki skor yang lebih tinggi pada kreatifitas, metalingual, dan membaca dibanding siswa yang hanya menguasai bahasa itali (Ricciardelli, 1993).

Berdasar pada teori belajar konstruktivisme yang mengutamakan keaktifan siswa dalam membangun pengetahuan dan konsep dalam dirinya sendiri (Suryosubroto, 1983: 12), alternatif media pembelajaran yang dapat digunakan di SBI adalah modul berbahasa Inggris. Jika modul dirancang sedemikian rupa dengan menggunakan bahasa Inggris yang mudah dipahami siswa, maka media ini akan memberikan kontribusi yang baik yaitu membantu meningkatkan motivasi dan pemahaman siswa, serta memperlancar penggunaan bahasa Inggris siswa.

Penelitian penggunaan modul dalam pembelajaran di R-SMA BI telah dilakukan sebelumnya oleh Monika Primasari (2010), Ririn Zarlina (2012), dan Manihar Situmorang dkk (2015) dengan materi yang berbeda, dimana hasil penelitian diperoleh bahwa hasil belajar siswa yang menggunakan modul berbahasa Inggris lebih tinggi secara signifikan dibandingkan siswa yang belajar tanpa menggunakan modul. Pada penelitian ini digunakan modul yang telah diuji coba kelayakannya sebagai media pembelajaran dikelas SBI. Salah satu modul yang diuji kelayakannya adalah modul berbahasa Inggris oleh Silvia Utari (2012) untuk materi laju reaksi di R-SMA-BI 10 Padang, namun belum di lakukan uji coba penggunaannya untuk pembelajaran disekolah RSBI. Oleh karena itu, penulis tertarik untuk melakukan penelitian dengan judul "Perbedaan Hasil Belajar Siswa Yang Belajar Dengan Menggunakan Modul Berbahasa Inggris Dan Buku Bilingual Pada Materi Laju Reaksi Kelas XI SMA". Dimana penelitian ini bertujuan untuk mengetahui perbedaan hasil belajar siswa yang belajar dengan menggunakan Modul berbahasa Inggris dan buku Bilingual pada Materi Laju Reaksi.

\section{Metode Penelitian}

Jenis penelitian ini adalah penelitian eksperimen dengan rancangan penelitian Randomized Control Group Only Design. Instrumen dalam penelitian ini berupa Tes akhir yang diberikan pada kelas eksperimen 1 dan kelas eksperimen 2.

Prosedur dalam penelitian ini meliputi:

- Tahap persiapan

Guru mempersiapkan segala sesuatu yang diperlukan untuk proses pembelajaran seperti RPP, bahan ajar, modul dll.

- Tahap pelaksanaan

Pada tahap pelaksanaan ini, dilakukan perlakuan yang berbeda terhadap dua kelas eksperimen, pada kelas eksperimen 1 dilakukan pembelajaran dengan menggunakan Modul Berbahasa Inggris, sedangkan pada kelas eksperimen 2, pembelajaran dilakukan seperti biasa yaitu pembelajaran 
Sekretariat: Jurusan Pendidikan IPA, Fakultas Matematika dan Ilmu Pengetahuan Alam, Universitas Negeri Padang - Jl. Prof. Dr. Hamka, Air Tawar Padang, Sumatera Barat

E-mail :prodiipa16@gmail.com, Halaman website : http://www.semesta.ppj.unp.ac.id/index.php/semesta.

Jurnal SEMESTA, Vol.01, No.01, 2017 pp. 6-12

konvensional dimana guru sebagai pusat pembelajaran dan digunakan buku bilingual sebagai buku panduannya.

- Tahap Penyelesaian

Analisis data dilakukan dengan langkah-langkah sebagai berikut : a) Mengumpulkan hasil data kuantitatif. b) Membandingkan hasil tes secara deskriptif pada kelas eksperimen 1 dan kelas eksperimen 2. c) Melakukan analisis data kuantitatif secara statistik terhadap hasil tes akhir. Pembuatan kesimpulan dilakukan dengan membuat kesimpulan dari data kuantitatif yang diperoleh, yaitu mengenai hasil belajar kimia siswa.

Instrument atau alat pengumpulan data dalam penelitian ini adalah tes. Tes dilakukan setelah materi selesai dipelajari. Tes berfungsi untuk mengetahui hasil belajar kimia siswa setelah diberi perlakuan dengan pembelajaran menggunakan modul laju reaksi berbahasa Inggris dan menggunakan buku bilingual. Tes yang digunakan adalah tes berbentuk objektif sebanyak 30 buah soal. Untuk melihat apakah suatu tes telah layak digunakan, maka dilakukan uji coba tes. Uji coba tes ini bertujuan untuk melihat validitas, indeks kesukaran, daya beda, dan reliabilitas tes dari soal tersebut. Pada penelitian ini akhirnya digunakan 20 buah soal yang telah di uji coba sehingga valid untuk digunakan sebagai alat ukur.

\section{Hasil dan Pembahasan}

\subsection{Deskripsi Data}

Data yang diambil dalam penelitian ini adalah nilai dari hasil tes yang dilakukan di akhir pembelajaran pada kelas eksperimen 1 dan kelas eksperimen 2.

3.2. Analisis Data

Analisis data dilakukan dengan cara berurutan, mulai dari perbedaan rata-rata kelas eksperimen 1 dan kelas eksperimen 2, uji normalitas, homogenitas, dan uji hipotesis kedua rata-rata.

\section{a. Perbedaan nilai rata-rata kelas eksperimen 1 dan kelas eksperimen 2}

Dari tes akhir yang diberikan, dilakukan perhitungan sehingga diperoleh nilai rata-rata $(\bar{X})$, simpangan baku (s), dan varians $\left(\mathrm{s}^{2}\right)$. Hasil penelitian menunjukkan bahwa rata-rata hasil belajar siswa di kelas eksperimen 1 lebih tinggi dibandingkan dengan kelas eksperimen 2 yaitu 89,06 dibandingkan dengan 70,00. Untuk menguji apakah terdapat perbedaan hasil belajar dari penggunaan modul berbahasa Inggris dan buku bilingual pada pembelajaran laju reaksi di kelas XI SMA, maka perlu dilakukan uji hipotesis.

\section{b. Pengujian hipotesis penelitian}

Sebelum melakukan uji hipotesis, perlu dilakukan uji normalitas dan uji homogenitas terhadap kelas sampel untuk menentukan rumus yang akan digunakan untuk menguji hipotesis, pada penelitian ini diperoleh pada kelas eksperimen 1 dan 2 nilai Lo < Lt, sehingga dapat disimpulkan kedua kelas dalam keadaan normal. Kemudian selanjutnya dilakukan uji homogenitas dimana F table $<\mathrm{F}$ hitung sehingga dapat disimpulkan bahwa data tidak homogen.

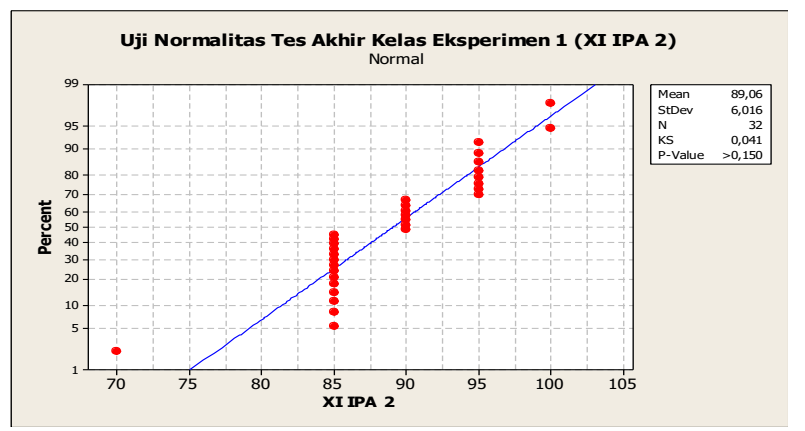

Gambar 1. Grafik Uji Normalitas Tes Akhir Kelas Eksperimen 1 
Sekretariat: Jurusan Pendidikan IPA, Fakultas Matematika dan Ilmu Pengetahuan Alam, Universitas Negeri Padang - Jl. Prof. Dr. Hamka, Air Tawar Padang, Sumatera Barat

E-mail :prodiipa16@gmail.com, Halaman website : http://www.semesta.ppj.unp.ac.id/index.php/semesta.

Jurnal SEMESTA, Vol.01, No.01, 2017 pp. 6-12

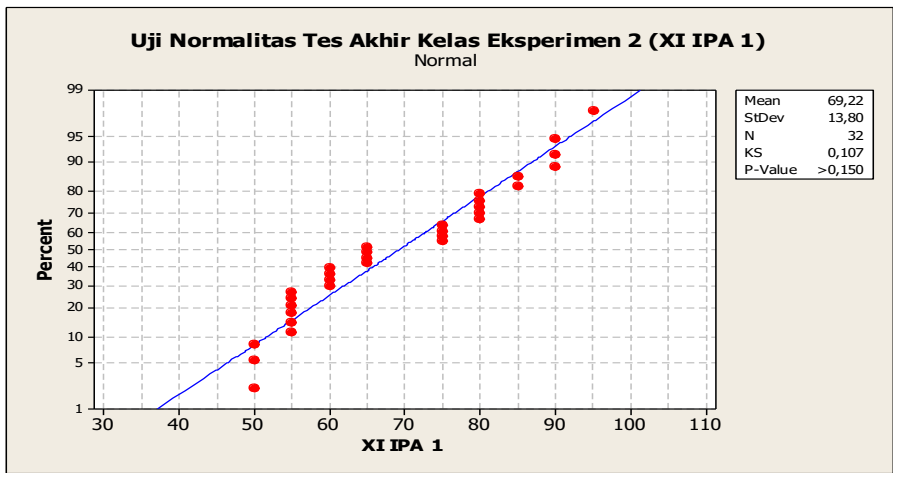

Gambar 2. Grafik Uji Normalitas Tes Akhir Kelas Eksperimen 2

Berdasarkan hasil uji normalitas dimana Lo $=0,098$ lebih kecil dari $\mathrm{Lt}=0,156$ pada kelas eksperimen $1, \mathrm{Lo}=0,1454$ lebih kecil dari $\mathrm{Lt}=0,156$ pada kelas eksperimen yang menunjukkan kedua kelas terdistribusi normal dan uji homogenitas diperoleh $\mathrm{F}$ hitung $=5,16$ lebih besar dari $\mathrm{F}$ tabel $=1,69$ yang berarti kedua kelompok memiliki varians yang tidak homogen, maka pengujian hipotesis harus dilakukan dengan uji-t', dengan data hasil pengujian diperoleh t' hitung bernilai 7,22 dan t' tabel sebesar 1,7. Sehingga nilai t tabel < dari t' hitung.

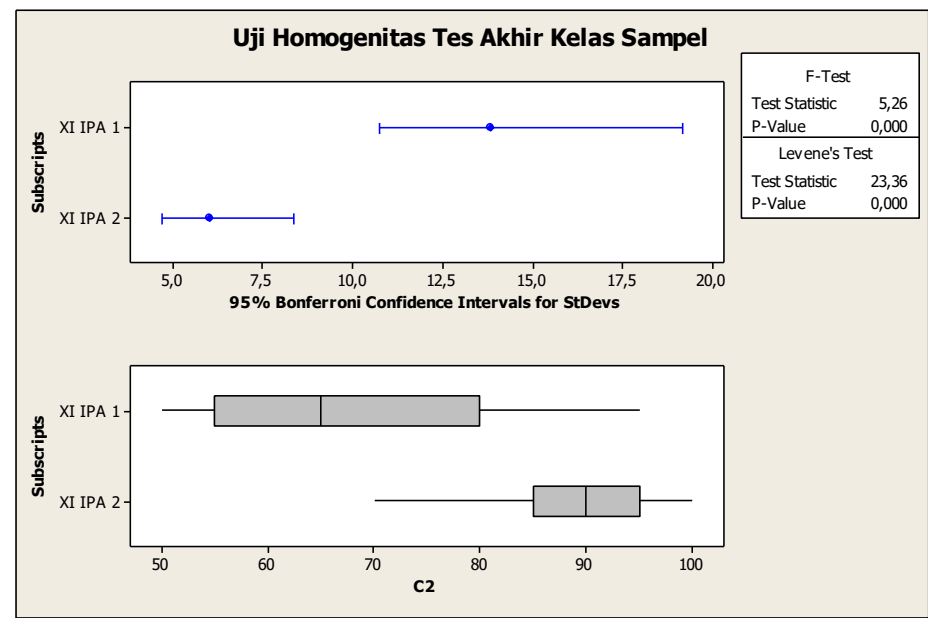

Gambar 3. Grafik Uji Homogenitas Kelas Sampel

Berdasarkan hasil uji-t' di atas, terlihat bahwa untuk $\mathrm{dk}=62$, t' hitung lebih besar dari $t$ tabel. Ini berarti hipotesis nol $\left(\mathrm{H}_{0}\right)$ ditolak dan hipotesis penelitian $\left(\mathrm{H}_{1}\right)$ diterima. Dengan kata lain, hasil belajar siswa pada pembelajaran dengan menggunakan modul berbahasa Inggris lebih tinggi secara signifikan dibandingkan hasil belajar siswa yang belajar dengan buku bilingual pada materi laju reaksi di kelas XI SMA.

Berdasarkan hasil analisis data yang telah dilakukan, diketahui bahwa hasil belajar siswa pada kelas eksperimen 1 lebih tinggi dibandingkan dengan hasil belajar siswa pada kelas eksperimen 2 . Hipotesis menyatakan bahwa hasil belajar kimia siswa pada pembelajaran dengan menggunakan modul laju reaksi berbahasa Inggris lebih tinggi secara signifikan dibandingkan hasil belajar kimia siswa yang belajar dengan buku bilingual di kelas XI SMA.

Modul yang digunakan penulis dalam upaya peningkatan hasil belajar siswa tersebut yaitu berupa modul berbahasa Inggris yang dapat melatih keterampilan siswa memahami materi pembelajaran dalam bahasa Inggris. Modul berbahasa Inggris yang digunakan ini memiliki keunggulan-keunggulan seperti, modul dikemas berdasarkan teori konstruktivisme sehingga siswa 
Sekretariat: Jurusan Pendidikan IPA, Fakultas Matematika dan Ilmu Pengetahuan Alam, Universitas Negeri Padang - Jl. Prof. Dr. Hamka, Air Tawar Padang, Sumatera Barat

E-mail :prodiipa16@gmail.com, Halaman website : http://www.semesta.ppj.unp.ac.id/index.php/semesta.

Jurnal SEMESTA, Vol.01, No.01, 2017 pp. 6-12

dapat membangun konsepnya sendiri, dimana pada akhir pelajaran siswa dapat menemukan konsep dalam bahasa inggris, dengan modul siswa dapat lebih mudah memahami konsep karena modul dibuat menggunakan bahasa Inggris yang sederhana. Modul dibuat berdasarkan karakteristik materi Laju Reaksi yang bersifat abstrak, sebagaimana yang dikemukakan Chandrasegaran (2007: 294) mengemukakan bahwa konsep-konsep dalam ilmu kimia direpresentasikan ke dalam tiga level representasi yaitu, representasi makroskopis, representasi submikroskopis, dan representasi simbolik. Modul berbahasa Inggris ini di dalamnya terdapat gambar-gambar yang dapat menjelaskan konsep Laju Reaksi secara makroskopis dan mikroskopis sehingga memudahkan siswa untuk berimajinasi memahami materi Laju Reaksi yang bersifat abstrak. Penggunaan modul ini juga dapat membuat siswa berpartisipasi lebih aktif dalam proses pembelajaran. Sesuai dengan yang dikemukakan Suryosubroto (1983: 12) bahwa modul dapat membangkitkan rangsangan kegiatan belajar dan meningkatkan aktifitas belajar.

Dilihat dari segi teori belajar dan prinsip-prinsip psikologi belajar sebagaimana yang dikemukakan Suryosubroto (1983: 22), modul yang digunakan telah tersusun secara sistematis dan sesuai dengan runtutan materi yang harus dipahami siswa, memuat tujuan pembelajaran, latihanlatihan, dan penerapan. Selain itu modul yang digunakan juga dirancang dengan mengunakan bahasa Inggris dengan menggunakan bahasa sederhana sehingga mudah dipahami siswa serta mengacu pada pembelajaran konstruktivisme. Dengan menggunakan modul siswa akan menggali konsep-konsep berbahasa Inggris yang ada pada modul dan membangun pengetahuannya sendiri dengan cara menyesuaikannya dengan pengalaman mereka atau konstruksi yang telah mereka miliki sebelumnya (Pannen, 2001: 4).

Modul merupakan salah satu media teknologi cetak, dengan menggunakan modul dapat membantu menyampaikan materi pelajaran dalam bentuk salinan tercetak dengan dua jenis tampilan yaitu verbal dan visual. Untuk dapat menarik perhatian siswa, agar siswa lebih termotivasi dan semangat dalam melakukan pembelajaran menggunakan media modul ini, tampilan modul secara keseluruhan harus diperhatikan. Oleh karena itu modul yang digunakan dirancang dalam bentuk sebuah buku yang dijilid rapi dan dengan tampilan cover yang menarik. Sebagai tambahan, modul ini memiliki daya tarik lebih yaitu karena tidak terlalu tebal, sehingga siswa tidak merasa terbebani untuk membawanya kemana-mana. Modul ini juga dirancang dengan menggunakan gambar-gambar makromolekul sehingga menuntun daya imajinasi siswa sehingga dapat lebih memahami konsepkonsep kimia yang ada didalam modul.

Dalam proses pembelajaran dibutuhkan strategi pembelajaran untuk meningkatkan keinginan siswa dalam belajar. Begitu pula pembelajaran dengan menggunakan media harus diterapkan juga strategi pembelajaran. Hal yang paling penting adalah bagaimana membelajarkan siswa dengan menggunakan media tersebut. Hal mendasar yang dibutuhkan dalam hal ini adalah motivasi. Menurut Elizar (2009: 18), siswa yang termotivasi akan memperlihatkan minat, mempunyai perhatian dan ingin berpartisipasi dalam kegiatan pembelajaran. Pada kenyataannya, tidak semua siswa memiliki motivasi yang cukup kuat untuk belajar. Disini lah tugas seorang guru untuk membangkitkan motivasi belajar siswa. Salah satu cara yang diterapkan untuk membangkitkan motivasi ini adalah dengan membiarkan rasa penasaran dan ingin tahu siswa ketika modul Laju Reaksi diberikan kepada siswa. Begitu memperoleh modul, siswa secara tidak sabar langsung membolak-balik halaman demi halaman dalam modul sambil melontarkan pertanyaan-pertanyaan. Untuk beberapa saat, pertanyaan-pertanyaan tersebut dibiarkan tak terjawab. Tujuannya adalah untuk mengusik perhatian siswa yang masih belum peduli pada modul yang diberikan.

Menarik perhatian dan menumbuhkan rasa ingin tahu siswa saja belum cukup untuk dapat membelajarkan siswa dan mencapai tujuan pembelajaran. Pada tahap ini guru memegang peranan penting yaitu sebagai organisator, yaitu guru berperan dalam mengatur jalannya pembelajaran. Disini dituntut bagaimana keterampilan guru dalam menggunakan modul ini. Proses pembelajaran menggunakan modul ini diawali dengan memberikan gambaran bagaimana cara menggunakan modul 
Sekretariat: Jurusan Pendidikan IPA, Fakultas Matematika dan Ilmu Pengetahuan Alam, Universitas Negeri Padang - Jl. Prof. Dr. Hamka, Air Tawar Padang, Sumatera Barat

E-mail :prodiipa16@gmail.com, Halaman website : http://www.semesta.ppj.unp.ac.id/index.php/semesta.

Jurnal SEMESTA, Vol.01, No.01, 2017 pp. 6-12

dalam pembelajaran, latihan-latihan yang harus dikerjakan, instruksi-instruksi khusus di setiap aktivitas, dan hasil akhir yang akan ditagih pada akhir pembelajaran. Hal ini bertujuan untuk memberikan gambaran yang jelas kepada siswa mengenai kegiatan pembelajaran dengan media modul. Dengan ini siswa dapat lebih terarah dalam kegiatan pembelajaran karena mereka telah mengetahui dengan jelas apa yang akan mereka lakukan.

Dalam kegiatan pembelajaran dengan menggunakan modul ini, proses komunikasi berlangsung multi arah, yaitu antara guru dengan siswa dan siswa dengan siswa. Hal ini didukung oleh kemampuan dasar siswa untuk berkomukasi dan berinteraksi yang memang sudah baik. Karena modul yang digunakan adalah modul berbahasa Inggris, maka seringkali interaksi yang terjadi mengandung kosakata dalam bahasa Inggris dan ini dapat membantu membiasakan siswa dalam memahami istilah-istilah berbahasa Inggris yang terkait dengan materi Laju Reaksi. Dengan adanya interaksi ini, partisipasi siswa dalam kegiatan pembelajaran menjadi semakin aktif. Semakin banyak aktivitas yang dilakukan siswa maka efektifitas pembelajaran semakin meningkat. Jadi aktivitas siswa tidak terbatas hanya dengan mendengar saja (Nasution, 1995: 6).

Dari segi interaksi dalam pembelajaran, baik antara siswa dengan guru maupun siswa dengan siswa terlihat berbeda antara kelas eksperimen 1 dengan kelas eksperimen 2. Di kelas eksperimen 1, dengan adanya modul interaksi yang terjalin lebih didominasi oleh interaksi siswa dengan siswa yang berdiskusi dalam menyelesaikan lembaran kegiatan dalam modul. Siswa lebih serius dan antusias dalam menemukan konsep berbahas Inggris dengan mengerjakan lembaran kegiatan dan lembaran kerja yang ada pada modul. Dengan adanya gambar pada modul, membuat pola pikir siswa lebih sistematis dan membantu dalam mengkonstruksi pemahamannya serta adanya warna membuat perhatian siswa lebih terfokus. Kegiatan pembelajaran seperti ini memungkinkan guru untuk berkeliling memantau siswa yang agak kesulitan atau kebingungan. Pembelajaran seperti ini merupakan salah satu cara untuk membuat pembelajaran tetap melekat dalam pikiran siswa sekaligus membentuk pengetahuan siswa. Sementara di kelas eksperimen 2, interaksi yang dominan terjadi adalah interaksi guru dengan siswa. Disini siswa menggunakan buku pegangan berupa buku bilingual dalam pembelajaran dan selama proses pembelajaran siswa hanya mendengarkan penjelasan tentang materi pembelajaran yang diberikan oleh guru dan kemudian mencatatnya sedangkan untuk memahami konsep dalam bahasa Inggris siswa diarahkan untuk menemukan sendiri dalam buku bilingual, sedangkan buku bilingual masih kurang efektif dan efisien penggunaannya karena berdasarkan pengalaman penulis di lapangan, siswa lebih berinisiatif untuk melihat konsep yang berbahasa Indonesia. Hal ini membuat siswa kesulitan dalam menginterpretasikan informasi verbal dan visual yang diberikan oleh guru dan yang terdapat di dalam buku. Selain itu mencatat materi pelajaran yang dilakukan oleh siswa memerlukan waktu lebih dan membuat siswa kurang aktif dalam proses pembelajaran.

Dari segi pengalaman belajar, pengetahuan yang diperoleh atas konstruksi sendiri akan bertahan lebih lama dalam memori siswa dibandingkan pengetahuan yang diterima siswa tanpa pengalaman belajar. Berdasarkan pengamatan dalam kegiatan pembelajaran pada masing-masing kelas tersebut, maka dapat diasumsikan bahwa perbedaan interaksi pada kedua kelas ini menyebabkan perbedaan hasil belajar pada kedua kelas. Penelitian ini telah berhasil membuktikan hasil penelitian sebelumnya bahwa pembelajaran dengan modul dapat meningkatkan hasil belajar siswa, dalam hal ini lebih dikhususkan bahwa temuan tersebut terbukti di kelas SBI.

\section{Kesimpulan}

Berdasarkan penelitian dan analisis data yang dilakukan dapat disimpulkan bahwa penggunaan modul Laju Reaksi berbahasa Inggris di sekolah RSBI memberikan pengaruh yang signifikan terhadap hasil belajar siswa dimana siswa yang belajar dengan modul memperoleh hasil belajar yang lebih tinggi dibanding siswa yang belajar dengan menggunakan buku bilingual. 
Sekretariat: Jurusan Pendidikan IPA, Fakultas Matematika dan Ilmu Pengetahuan Alam, Universitas Negeri Padang - Jl. Prof. Dr. Hamka, Air Tawar Padang, Sumatera Barat

E-mail :prodiipa16@gmail.com, Halaman website : http://www.semesta.ppj.unp.ac.id/index.php/semesta.

Jurnal SEMESTA, Vol.01, No.01, 2017 pp. 6-12

\section{Ucapan Terima Kasih}

Penulis mengucapkan terima kasih kepada Ibu Prof Dr. Hj. Ellizar, M.Pd dan Ibu Dra. Andromeda, M.Si serta seluruh staf pengajar jurusan kimia FMIPA UNP.

\section{Daftar Pustaka}

Chandrasegaran, A.L. 2007. The Development of a Two-Tier Multiple-Choice Diagnostic Instrument for Evaluating Secondary School Students' Ability to Describe and Explain Chemical Reactions Using Multiple Levels of Representation. Australia: Department of Applied Chemistry, Curtin University of Technology.

Ellizar. 2009. Pengembangan Program Pengajaran Kimia. Padang: FMIPA IKIP.

Foster, K. M., \& Reeves, C. K. (1989). Foreign Language in the Elementary School (FLES) improves cognitive skills. FLES News, 2(3), 4.

Landry, R. G. (1973). The enhancement of figural creativity through second language learning at the elementary school level. Foreign Language Annals, 7(1), 111-115.

Nasution, M.A. 2008. Berbagai Pendekatan dalam Proses Belajar dan Mengajar. Jakarta: PT Bumi Aksara.

Pannen, Paulina. 2001. Konstruktivisme dalam Pembelajaran. Jakarta: PAU-PPAI Universitas Terbuka.

Primasari, M. 2010. "Pengaruh penggunaan Modul Pokok Bahasan Minyak Bumi terhadap Hasil Belajar Siswa Kelas X R-SBI 10 Padang”. Skripsi. Padang: Universitas Negeri Padang.

Ricciardelli, L. A. (1993). An investigation of the cognitive development of Italian-English bilinguals and Italian monolinguals from Rome. Journal of Multilingual and Multicultural Development, 14(4), 345-346.

Silvia, U. 2012. "Pembuatan Modul Laju Reaksi Berbahasa Inggris Untuk Pembelajaran Kimia Kelas XI R-SMA-BI 1 Padang”. Skripsi. Padang: Universitas Negeri Padang.

Situmorang, M., Sitorus, M., Hutabarat, W., dan Situmorang, Z. 2015. "The Development of Innovative Chemistry Learning Material for Bilingual Senior High School Students in Indonesia". International Education Studies; Vol. 8, No. 10; 2015: Canadian Center of Science and Education

Suryosubroto. B. 1983. Sistem Pengajaran dengan Modul. Yogyakarta: Bina Aksara.

Tim Penyusun. 2010. Pedoman Penyusunan Skripsi Mahasiswa MIPA. Padang: UNP Press.

Triwiyanto, T., dan Ahmad Yusuf. 2010. Panduan Mengelola Sekolah Bertaraf International. Jogjakarta: Ar ruzz media.

Zarlina, Ririn. 2012. Pengaruh Penggunaan Modul Hidrolisis Garam Berbahasa Inggris terhadap Hasil belajar Siswa Kelas XI R-SMA BI 10 Padang. Skripsi. Padang: Jurusan Kimia FMIPA UNP. 